\title{
E-learning in new normal COVID-19 era: Measure HOTS and pro-environmental behavior about environmental pollution
}

\author{
Ilmi Zajuli Ichsan ${ }^{1}$, Agung Purwanto ${ }^{2}$, Henita Rahmayanti ${ }^{3}$ \\ ${ }^{1,2,3}$ Doctoral Program of Population and Environmental Education, Universitas Negeri Jakarta, Indonesia \\ ${ }^{1}$ Department of Elementary Teacher Education, Universitas Mohammad Husni Thamrin Jakarta, Indonesia
}

\begin{abstract}
Article Info
Article history:

Received Dec 22, 2020

Revised Jun 2, 2021

Accepted Jul 17, 2021

Keywords:

COVID-19

E-learning

HOTS

New normal

Pro-environmental behavior

ABSTRACT

Current environmental learning amid the COVID-19 new normal situation requires an innovation. This is due to students need various skills to solve environmental pollution issues using Higher Order Thinking Skills (HOTS) and is implemented in the form of Pro-Environmental Behavior (PEB). The innovation is aimed at supporting e-learning utilization. This study aims to delineate university students' HOTS and PEB and examine the e-learning utilization. Method used in the study is descriptive method using survey technique. Samples involved in the research are 265 university students. The study results indicate that the students' HOTS score is, overall, in a very low category (31.37). The students' PEB score, however, is already in a very high position (89.88) as a form to prevent COVID-19 in their surrounding environment. The result of e-learning description suggests that there are still some obstacles in terms of e-learning implementation. The research concludes that the HOTS score is relatively low, whereas the PEB score must be maintained. Suggestions proposed from this study is that to develop teaching materials or learning media, in this context book or supplementary book can be develop, related to environmental pollution as a disaster mitigation effort amid the COVID-19 new normal situation.
\end{abstract}

This is an open access article under the CC BY-SA license.

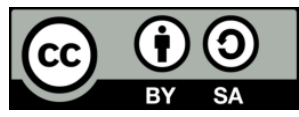

Corresponding Author:

Agung Purwanto

Doctoral Program of Population and Environmental Education

Universitas Negeri Jakarta

Rawamangun Muka Street, East Jakarta, Jakarta, Indonesia

Email: agungpurwanto@unj.ac.id

\section{INTRODUCTION}

Technology-based education during the Coronavirus Disease 2019 (COVID-19) requires an innovation [1]-[3]. It is in particularly environmental education at student level. There are numerous concepts must be delivered to the students related to efforts to prevent COVID-19 in the environmental aspect. It is because countless environmental factors effecting the spread of COVID-19 in urban areas. Issues associated to disaster mitigation knowledge to forestall environmental pollution experience some obstacles. Lack of information causes difficulties in overcoming the issues [4], [5]. It will give impact on the complexity in controlling the spread of COVID-19 in the communities' neighborhood. It creates the to-date strict restrictions to be looser. Efforts to maintain health protocol, however, must be strengthened.

Community awareness to protect the environment highly depends on their knowledge of environmental pollution issues. In this context, knowledge of Higher Order Thinking Skills (HOTS) is a necessity [6]-[8]. Moreover, it also requires an effort to be able to implement the concept in the form of ProEnvironmental Behavior (PEB). Various studies related to HOTS that have been conducted are a description 
of students' HOTS in environmental context, especially environmental pollution that entails mitigation to prevent disaster [9]. The results of those studies indicated that the students' HOTS in the environmental context was still in a low category. Additionally, a development of various educational models has been carried out to improve the HOTS [7], [10], [11]. The development, however, is deemed less optimal in improving the HOTS. Moreover, studies related to PEB have also been conducted in terms of PEB profile in the communities [12]-[14]. PEB can be empowered using learning media. Another effort accomplished is the development of community-based educational model for environmental conservation [15]. Learning media have also been started to be work out to cope with the low student awareness to recycle [3]. Another development is involving books or modules to enhance students' abilities in ecosystem topic [16], [17].

Related to the research, e-learning implementation is also an important part of education. Various studies on e-learning have been conducted as a form of technology implementation in education [18]-[21]. It is due to the new normal situation that obliges e-learning or online learning-based educational activities. Both terms are basically the same yet e-learning is more comprehensive. Several studies on e-learning indicate that e-learning is crucial in the learning [22]-[24]. Those studies, however, have not clearly pointed out various obstacles as well as issues faced by the students in the e-learning system.

The aforementioned shows that a description on students' HOTS in the environmental pollution context is required as well as students' PEB in preventing COVID-19. The study is a novelty as previous studies have not conducted detail description on HOTS and PEB in environmental pollution and description of analysis related to the effectiveness of e-learning from users' points of view. This is intended at supporting efforts to continuously strengthen e-learning during the new normal period. This study aims to perform a description analysis of HOTS, PEB, and e-learning at university level. This study is urgent and important as an effort to innovate amid the pandemic. This study aimed to perform a measurement and description analysis of HOTS, PEB, and e-learning at university level. This study is urgent and important as an effort to innovate amid the pandemic.

\section{RESEARCH METHOD}

The research carried out during the COVID-19 new normal period in November 2020-February 2021. Method used was descriptive using survey analysis technique. Samples involved in the research were randomly selected from several universities in Jakarta and surrounding Area. University include in this research were university that have several Program Study, this is to minimize bias for selected samples. Total samples 265 university students, divided into 178 students filled HOTS instruments and 87 students filled PEB instruments and opinion on e-learning.

The research instrument consisted of three instruments, namely: test questions to measure students' HOTS, instrument to measure PEB, and instrument to identify students' opinion on the e-learning implementation. The HOTS indicators comprised of six indicators contained in 12 items as seen in Table 1. There was one indicator about Environmental Impact Analysis.

In terms of PEB, there were three indicators contained in 10 items to measure students' behavior as seen in Table 2. The indicators were adapted from previous research [2] with small modification since questions were given to different samples. The instruments were created for various levels and validity test had been previously conducted.

Table 1. Indicators of HOTS instruments on environmental pollution

\begin{tabular}{cllc}
\hline No & & \multicolumn{1}{c}{ Indicators } & \\
\hline 1 & Analyze flood-causing factors and recycle habits & & Item \\
2 & Analyze the impacts of river pollution & & 3,2 \\
3 & Evaluate sustainable development programs in urban areas & 5,6 \\
4 & Criticize plastic utilization & 7,8 \\
5 & Create innovative ideas so that environmental impact analysis can be employed to solve environmental problems & 9,10 \\
6 & Create innovative programs to maintain the environment & 11,12 \\
\hline
\end{tabular}

Table 2. Indicators of PEB instruments

\begin{tabular}{clc}
\hline No & \multicolumn{1}{c}{ Indicators } & Item \\
\hline 1 & Clean house areas and environment to prevent COVID-19 & $1,2,3$ \\
2 & Avoid crowds to evade COVID-19 & $4,5,6$ \\
3 & Reduce interaction with various objects to prevent COVID-19 & $7,8,9,10$ \\
\hline
\end{tabular}


HOTS instrument has been validated. The results show that all items have a valid category. This is based on the validity test. Meanwhile, the reliability of the HOTS instrument is 0.84 which means that this instrument is reliable. All items are valid at the 0.01 level which can be seen in Table 3 .

PEB instrument items as a whole have a valid category. This shows that all items can be used for measurement. The reliability value obtained is 0.83 which means that this instrument can be used. In more detail, all the validity test results can be seen in Table 4 .

Table 3. The results of the HOTS item validity test

\begin{tabular}{ccc}
\hline Item no & Pearson correlation & Category \\
\hline 1 & $.687^{* *}$ & Valid \\
2 & $.787^{* *}$ & Valid \\
3 & $.698^{* *}$ & Valid \\
4 & $.478^{* *}$ & Valid \\
5 & $.546^{* *}$ & Valid \\
6 & $.669^{* *}$ & Valid \\
7 & $.519^{* *}$ & Valid \\
8 & $.544^{* *}$ & Valid \\
9 & $.702^{* *}$ & Valid \\
10 & $.539^{* *}$ & Valid \\
11 & $.583^{* *}$ & Valid \\
12 & $.614^{* *}$ & Valid \\
\hline$* *$ significant at the $0.01 ; *$ significant at the 0.05
\end{tabular}

Table 4. The results of the validity test of PEB items

\begin{tabular}{ccc}
\hline Item no & Pearson correlation & Category \\
\hline 1 & $.520 * *$ & Valid \\
2 & $.493 * *$ & Valid \\
3 & $.627 * *$ & Valid \\
4 & $.733 * *$ & Valid \\
5 & $.674 * *$ & Valid \\
6 & $.740 * *$ & Valid \\
7 & $.677 * *$ & Valid \\
8 & $.692 * *$ & Valid \\
9 & $.610^{* *}$ & Valid \\
10 & $.580^{*} *$ & Valid \\
\hline$* *$ significant at the $0.01 ; *$ significant at the 0.05
\end{tabular}

Questions related to e-learning were put in the form of opinion that must be filled by the students. Data analysis employed in the research was descriptive analysis using software of Microsoft Excel and Statistical Package for the Social Sciences (SPSS). The analysis results were then interpreted in score categories that consisted of very high, high, moderate, low, and very low as shown in Table 5. This was to facilitate process data in measuring students' abilities.

Table 5. Score categories of students' HOTS and PEB

\begin{tabular}{cc}
\hline Category & Interval of students' HOTS score \\
\hline Very high & $\mathrm{X}>81.28$ \\
High & $70.64<\mathrm{X} \leq 81.28$ \\
Moderate & $49.36<\mathrm{X} \leq 70.64$ \\
Low & $38.72<\mathrm{X} \leq 49.36$ \\
Very low & $\mathrm{X} \leq 38.72$ \\
\hline Category and interval score adapted from Ichsan, et al. [9]
\end{tabular}

\section{RESULTS AND DISCUSSION}

The research results indicated that the students' HOTS score was still in a very low category. It was due to the low students' understanding of efforts in mitigating the environmental disasters. Item with the lowest score was item no. 7 that related to criticize community behaviors that still use plastic bags for foods as can be seen in Table 6. This suggested that students were unable to give effective criticism to prevent adverse impacts of the environmental pollution. This would bring consequences on the occurrence of environmental disasters. Students' score for male and female also indicated a low score as shown in Table 7. 
Similar to the research results for each item, the research results for each indicator also suggested that the students' HOTS score was low in terms of criticism to the use of plastic. This confirmed that students still incapable of providing concrete solutions to problems of the large number of plastics circulating in the society.

Table 6. Students' HOTS score related to environmental pollution

\begin{tabular}{|c|c|c|c|c|}
\hline No & Item & All & Male & Female \\
\hline 1 & $\begin{array}{l}\text { Floods that frequently occur in urban areas causes numerous social and economic } \\
\text { disturbances in the communities; provide your analysis results in this matter }\end{array}$ & 4.90 & 4.63 & 5.23 \\
\hline 2 & $\begin{array}{l}\text { Accumulated garbage in urban areas can be further processed to preserve the environment. } \\
\text { Provide your analysis on what factors that cause the people to refuse to recycle }\end{array}$ & 3.70 & 3.43 & 4.02 \\
\hline 3 & $\begin{array}{l}\text { Siltation of river due to the large amount of garbage has inhibited water flow. Provide your } \\
\text { analysis on why the people still littering? }\end{array}$ & 3.23 & 3.06 & 3.43 \\
\hline 4 & $\begin{array}{l}\text { Make a systematic analysis related to environmental impact analysis functions in maintaining } \\
\text { the environment }\end{array}$ & 3.26 & 3.21 & 3.32 \\
\hline 5 & Give an opinion related to sustainable development that is difficult to realize in the daily life. & 2.67 & 2.54 & 2.83 \\
\hline 6 & Evaluate what the students can do to support sustainable development program! & 2.90 & 2.72 & 3.11 \\
\hline 7 & $\begin{array}{l}\text { Give criticism of people's behavior that still carry plastic bag as a food container despite a } \\
\text { regulation that prohibit plastic bag utilization }\end{array}$ & 2.58 & 2.39 & 2.82 \\
\hline 8 & $\begin{array}{l}\text { Give criticism and suggestion related to the policy of paid-plastic use, do you think the } \\
\text { policy is effective? }\end{array}$ & 2.92 & 2.65 & 3.23 \\
\hline 9 & $\begin{array}{l}\text { Create a doable solution to problems to overcome the issue of low community awareness in } \\
\text { maintaining the environment. }\end{array}$ & 3.19 & 3.00 & 3.40 \\
\hline 10 & $\begin{array}{l}\text { environmental impact analysis as a way to prevent environmental issues is deemed less } \\
\text { effective; provide an innovative idea so that environmental impact analysis could be a means }\end{array}$ & 2.71 & 2.59 & 2.84 \\
\hline 11 & $\begin{array}{l}\text { Provide an innovative solution so that environmental impact analysis and other regulations } \\
\text { can be implemented and obeyed to mitigate disasters }\end{array}$ & 2.66 & 2.49 & 2.87 \\
\hline 12 & $\begin{array}{l}\text { Create a simple program to surmount problem of low students' awareness to decrease the } \\
\text { impacts of floods in urban areas }\end{array}$ & 2.92 & 2.75 & 3.11 \\
\hline & Raw score & 37.64 & 35.46 & 40.21 \\
\hline & Average score (interval 0-100) & 31.37 & 29.55 & 33.51 \\
\hline \multirow{2}{*}{\multicolumn{2}{|c|}{ Category }} & Very & Very & Very \\
\hline & & low & low & low \\
\hline
\end{tabular}

Table 7. Students' HOTS score related to environmental pollution for each indicator

\begin{tabular}{clccc}
\hline No & \multicolumn{1}{c}{ Indicators } & All & Male & Female \\
\hline 1 & Analyze flood-causing factors and recycle habits & 4.30 & 4.03 & 4.63 \\
2 & Analyze the impacts of river pollution & 3.24 & 3.14 & 3.37 \\
3 & Evaluate sustainable development programs in urban areas & 2.79 & 2.63 & 2.97 \\
4 & Criticize plastic utilization & 2.75 & 2.52 & 3.02 \\
5 & Create innovative ideas so that environmental impact & 2.95 & 2.80 & 3.12 \\
& analysis can be employed to solve environmental problems & & & \\
6 & Create innovative programs to maintain the environment & 2.79 & 2.62 & 2.99 \\
\hline
\end{tabular}

The HOTS score in various aspects suggested that the lowest score was in evaluate aspect. It corresponds to previous finding stating that the lowest indicator was in those related to evaluation. The results are presented in detail in Table 8.

As regards the students' PEB score in coping with the COVID-19 impacts from environmental aspect indicated that the score was generally in a very high category. This signified that the students had made every effort to maintain their environment during the pandemic. In several items, however, the score was low. Those items were, among others, shaking hand with other people as can be seen in Table 9. It was unavoidable as people have a habit to shake hands when they meet. Male and female students showed no differences as they had low score in the item.

The score for each indicator indicated that indicator with the lowest score was the third indicator that related to reducing interaction with COVID-19 potential transmission as seen in Table 10. This brought difficulty to students to handle it. Both male and female students had a low score in the indicator. Indicator with the highest score was the first indicator, which was clean the house environment to prevent COVID-19. This surely will be easier to perform yet strict health protocol supervision is still required. 
Table 8. Students' HOTS score related to environmental pollution for each aspect

\begin{tabular}{ccccc}
\hline No & Aspect & All & Male & Female \\
\hline 1 & Analyze & 3.77 & 3.58 & 4.00 \\
2 & Evaluate & 2.77 & 2.57 & 3.00 \\
3 & Create & 2.87 & 2.71 & 3.05 \\
\hline
\end{tabular}

Table 9. Students' PEB related to COVID-19 for each item

\begin{tabular}{|c|c|c|c|c|}
\hline No & Item & All & Male & Female \\
\hline 3 & The cleanliness of air circulation in my house is maintained to prevent contracting COVID-19 & 4.64 & 4.57 & 4.65 \\
\hline 5 & I stay away from dirty and crowded places & 4.63 & 4.29 & 4.66 \\
\hline 6 & I have minimized travelling to populated neighborhood to avoid COVID-19 & 4.53 & 4.29 & 4.55 \\
\hline 7 & $\begin{array}{l}\text { I keep away from touching various metal utensils and media that have potential to transmit } \\
\text { COVID-19 }\end{array}$ & 4.23 & 3.43 & 4.30 \\
\hline 9 & I shook hand without touching to reduce the impact of COVID-19 & 4.15 & 3.57 & 4.20 \\
\hline \multirow[t]{5}{*}{10} & If I found garbage in my neighborhood, I will throw it away to prevent the spread of COVID-19 & 4.51 & 3.86 & 4.56 \\
\hline & Raw score & 44.94 & 40.87 & 45.29 \\
\hline & Average score (interval 0-100) & 89.88 & 81.74 & 90.58 \\
\hline & Category & Very & Very & Very \\
\hline & & high & high & high \\
\hline
\end{tabular}

Table 10. Students' PEB related to COVID-19 for each indicator

\begin{tabular}{clccc}
\hline No & \multicolumn{1}{c}{ Indicators } & All & Male & Female \\
\hline 1 & Clean house areas and environment to prevent COVID-19 & 4.59 & 4.33 & 4.61 \\
2 & Avoid crowds to evade COVID-19 & 4.57 & 4.29 & 4.59 \\
3 & Reduce interaction with various objects to prevent COVID-19 & 4.37 & 3.75 & 4.42 \\
\hline
\end{tabular}

Regarding the results of survey on e-learning benefits, $64.37 \%$ students agreed that the e-learning was beneficial in learning, whereas $49.43 \%$ students felt that content delivery using e-learning was fairly effective. Moreover, $41.38 \%$ students stated that test using e-learning was fairly effective. The results are presented in Table 11.

Students were also given questions related to the use of Wi-Fi at home and the results indicated that the majority of the students did not use Wi-Fi as shown in Table 12. In addition, another finding also suggested that the majority of the students agreed with discussion activity through e-learning. This implied that discussion still occurred in the e-learning utilization. Similarly, the majority of the students agreed regarding comments or opinions given during question and answer session.

Table 11. Online learning benefits, effectiveness of content delivery and test effectiveness

\begin{tabular}{lccc}
\hline & Option & Number of respondents & Percentage \\
\hline Online learning benefits in & Strongly agree & 6 & 6.90 \\
learning & Agree & 56 & 64.37 \\
& Uncertain & 14 & 16.09 \\
& Disagree & 10 & 11.49 \\
& Strongly disagree & 1 & 1.15 \\
Effectiveness of content & Very effective & 4 & 4.60 \\
delivery with online learning & Effective & 23 & 26.44 \\
& Fairly effective & 43 & 49.43 \\
& Ineffective & 15 & 17.24 \\
Test effectiveness using & Very ineffective & 2 & 2.30 \\
online learning & Very effective & 2 & 2.30 \\
& Effective & 17 & 19.54 \\
& Fairly effective & 36 & 41.38 \\
& Ineffective & 27 & 31.03 \\
& Very ineffective & 5 & 5.75 \\
\hline
\end{tabular}


Table 12. Students' opinion on activities during online learning

\begin{tabular}{lccc}
\hline & Option & Number of respondents & Percentage \\
\hline The use of Wi-Fi at home & Yes & 34 & 39.08 \\
& No & 53 & 60.92 \\
Discussion occurs in online learning & Strongly agree & 5 & 5.75 \\
& Agree & 63 & 72.41 \\
Students gave responses during & Uncertain & 19 & 21.84 \\
question and answer session & Strongly agree & 5 & 5.75 \\
& Agree & 54 & 62.07 \\
& Uncertain & 25 & 28.74 \\
& Disagree & 3 & 3.45 \\
\hline
\end{tabular}

The research results indicated that the students' HOTS score was still in a very low category. This was due to the lack of HOTS-based teaching materials, learning media, and worksheets. The lack was related to the use of HOTS-based teaching materials and learning media is still relatively difficult to find. Many teaching materials and learning media are oriented to content delivery instead of a HOTS-based [6], [16], [25]. This renders difficulties to students in improving their HOTS to solve various environmental problems. HOTS in solving environmental problems is an important matter, especially for various complex issues such as environmental pollution. Different concepts related to the environmental pollution need further analysis [26]-[29]. Moreover, evaluation must be trained so that students could give criticism and opinion related to various environmental problems. Another skill is related to creating solutions to solve environmental problems.

The research results suggested that the PEB scores were already high since students were capable of implementing basic knowledge concept of COVID-19. The PEB also related to efforts to prevent environmental pollution. This is in line with the current situation that entering the COVID-19 new normal era. This new normal era will require planning efforts to prevent COVID-19 from the environmental aspect. This is because there are many students' behaviors that are hard to prevent in reducing the transmission of COVID-19. One of them involves the efforts to avoid physical contact such as shaking hand or contact with metal objects. Efforts to provide further information related to the PEB must be carried out through environmental education [30]-[32].

Environmental learning, in this regard, needs to innovate so that students could understand various advanced concepts from the environmental pollution. Therefore, it is necessary for university students to possess HOTS in the 21st century [33]-[36]. Students are expected to become an agent of change in their surrounding communities as they have knowledge to be implemented in the form of PEB so that the environmental pollution problem could be solved. Various teaching materials and learning media development can be a form of innovation in environmental education. The developed teaching materials and learning media should be HOTS-based. The contents must have a sequence and steps to train the HOTS and to improve the students' PEB.

The 21 st century environmental education is a new innovation of technology-based learning. The elearning utilization becomes an alternative of option and solution to difficulties of long-distance learning access [13], [37]-[41]. One of them is related to physical distancing policy. The policy has hindered face-toface learning in the classroom. The e-learning also faces several obstacles during the new normal COVID-19 era. The obstacles include less preparation in terms of facilities and infrastructures in implementing elearning. Moreover, e-learning utilization effectiveness still requires further evaluation to have adequate facilities. E-learning becomes a momentous necessity as it is the only learning system for long-distance learning. Media and teaching materials development need to be strengthened and must be in a digital-based form, it can be for develop supplementary book. This is to support the e-learning. Topics that can be developed in the teaching materials and learning media are those related to environmental pollution and disaster mitigation. The reason is that it is suitable to the current new normal condition.

\section{CONCLUSION}

The research concluded that the university students' HOTS score in the environmental pollution context was still very low. The PEB score, however, was already in a high category and needed to be maintained. During the COVID-19 new normal condition, an effort must be conducted to improve the students' HOTS and PEB through various innovations in environmental learning. One of the innovations was innovative teaching materials and learning media to be used in the e-learning. Topics developed in the media and teaching materials could be related to environmental pollution in mitigating disasters. Book or Supplementary book can be developed in future. The research suggested developing various teaching materials and learning media to improve students' HOTS and PEB during the COVID-19 new normal situation. 


\section{ACKNOWLEDGEMENTS}

Thank you for Indonesia Ministry of Education, Culture, Research and Technology (Kementerian Pendidikan, Kebudayaan, Riset, dan Teknologi Republik Indonesia) for funding this research in 2021 for Doctoral Dissertation Research Grants Number: 1/E4.1/DSD/LPPM/2021 (Penelitian Dasar Tahun Tunggal). Thank you for support from National Research and Innovation Agency (Badan Riset dan Inovasi Nasional) and Universitas Negeri Jakarta.

\section{REFERENCES}

[1] M. D. G. Allo, "Is the online learning good in the midst of COVID-19 Pandemic? The case of EFL learners," Jurnal Sinestesia, vol. 10, no. 1, pp. 1-10, 2020.

[2] I. Z. Ichsan, et al., "PEB-COVID-19: Analysis of students behavior and ILMIZI model in environmental learning," Jurnal Iqra': Kajian Ilmu Pendidikan, vol. 5, no. 1, pp. 1-11, 2020.

[3] A. Purwanto, I. Z. Ichsan, P. W. P. Gomes, Md M. Rahman, and Irwandani "ESBOR during COVID-19: Analysis students attitude for develop 21st century environmental learning," Journal of Sustainability Science and Management, vol. 15, no. 7, pp. 20-29, 2020.

[4] M. J. Sethusha and M. W. Lumadi, "Grade Six Learners' Perceptions of Environmental Awareness: A Human Ecological Support Programme," Journal of Human Ecology, vol. 42, no. 2, pp. 113-123, 2013.

[5] S. S. Ashraf, M.A. Rauf, and F. H. Abdullah, "A hands-on approach to teaching environmental awareness and pollutant remediation to undergraduate chemistry students," Research in Science and Technological Education, vol. 30, no. 2, pp. 173-184, 2012.

[6] I. Z. Ichsan and H. Rahmayanti, "HOTSEP: Revised Anderson's taxonomy in environmental learning of COVID19," European Journal of Educational Research, vol. 9, no. 3, pp. 1257-1265, 2020.

[7] H. Rahmayanti, I. Z. Ichsan, S. A. Azwar, D. A. Purwandari, N. Pertiwi, C. K. S. Singh, and P. W. P. Gomes, "DIFMOL: Indonesian students' HOTS and environmental education model during COVID-19," Journal of Sustainability Science and Management, vol. 15, no. 7, pp. 10-19, 2020.

[8] L. C. Garcia, "Environmental science issues for higher-order thinking skills (HOTS) development: A case study in the Philippines," In Biology Education and Research in a Changing Planet. Springer, Singapore, 2015, pp. 45-54.

[9] I. Z. Ichsan, D. V. Sigit, M. Miarsyah, A. Ali, W. P. Arif, and T. A. Prayitno, "HOTS-AEP: Higher order thinking skills from elementary to master students in environmental learning," European Journal of Educational Research, vol. 8, no. 4, pp. 935-942, 2019.

[10] H. Husamah, D. Fatmawati, and D. Setyawan, "OIDDE learning model: Improving higher order thinking skills of biology teacher candidates," International Journal of Instruction, vol. 11, no. 2, pp. 249-264, 2018.

[11] I. Z. Ichsan, "ILMIZI: Innovation learning model for natural science and environmental learning based on HOTS," International Journal for Educational and Vocational Studies, vol. 1, no. 6, pp. 578-584, 2019.

[12] N. C. Bronfman, et al., "Understanding attitudes and pro-environmental behaviors in a chilean community," Sustainability, vol. 7, no. 10, pp. 14133-14152, 2015.

[13] E. P. Azrai, D. V. Sigit, E. Heryanti, I. Z. Ichsan, Y. P. Jajomi, and R. Fadrikal, "Green consumerism among students: A survey in campus," Journal of Physics: Conference Series, 1317, pp. 012200, 2019.

[14] E. Durr, et al., "Are Beliefs in the Importance of Pro-Environmental Behaviors Correlated with Pro-Environmental Behaviors at a College Campus?" Sustainability: The Journal of Record, vol. 10, no. 3, pp. 204-210, 2017.

[15] D. V. Sigit, et al., "EECN: Analysis, potency, benefit for students knowledge and attitude to conserve mangroves and coral reefs," International Journal of Instruction, vol. 13, no. 1, pp. 125-138, 2020.

[16] M. Miarsyah, et al., "MEBA: Development android-based ecosystem module for senior high school students," Indian Journal of Public Health Research and Development, vol. 10, no. 8, pp. 2114-2118, 2019.

[17] D. V. Sigit, E. P. Azrai, E. Heryanti, I. Z. Ichsan, Y. P. Jajomi, and R. Fadrikal, "Development green consumerism e-book for undergraduate students (gc-ebus) as learning media in environmental learning," Indian Journal of Public Health Research and Development, vol. 10, no. 8, pp. 2026-2031, 2019.

[18] O. Derevenskaia, "Active learning methods in environmental education of students," Procedia - Social and Behavioral Sciences, vol. 131, pp. 101-104, 2014.

[19] M. Grosch, "Which media services do students use in fact? Results of an international empirical survey," Procedia - Social and Behavioral Sciences, vol. 141, pp. 795-806, 2014.

[20] J. Reyna, et al., "The Internet explosion, digital media principles and implications to communicate effectively in the digital space," E-Learning and Digital Media, vol. 15, no. 1, pp. 36-52, 2018.

[21] A. F. Lai, H.-Y. Lai, W.-H. Chuang, and Z.-H. Wu, "Developing a mobile learning management system for outdoors nature science activities based on $5 \mathrm{E}$ learning cycle," Proceedings of the International Conference on ELearning, 2015, pp. 59-65.

[22] N. Hidayati and A. I. Wuryandari, "Media Design for Learning Indonesian in Junior High School Level," Procedia - Social and Behavioral Sciences, vol. 67, pp. 490-499, 2012.

[23] M. A. Tkachuck, et al., "Natural disaster preparedness in college students: Implications for institutions of higher learning," Journal of American College Health, vol. 66, no. 4, pp. 269-279, 2018.

[24] K. Mccutcheon, M. Lohan, M. Traynor, and D. Martin "A systematic review evaluating the impact of online or blended learning vs. face-to-face learning of clinical skills in undergraduate nurse education," Journal of Advanced Nursing, vol. 71, no. 2, pp. 255-270, 2015. 
[25] E. Istiyono, W. S. B. Dwandaru, R. Setiawan, and I. Megawati, "Developing of computerized adaptive testing to measure physics higher order thinking skills of senior high school students and its feasibility of use," European Journal of Educational Research, vol. 9, no. 1, pp. 91-101, 2020.

[26] D. H. Santi, et al., "Problem solving process and creative thinking of students in ecosystem issue," JPBI (Jurnal Pendidikan Biologi Indonesia), vol. 5, no. 3, pp. 537-548, 2019.

[27] A. M. S. Hamouda and F. Tarlochan, "Engaging engineering students in active learning and critical thinking through class debates," Procedia - Social and Behavioral Sciences, vol. 191, pp. 990-995, 2015.

[28] A. Suryanda, et al., "Analogy and critical thinking skills: Implementation learning strategy in biodiversity and environment topic," Universal Journal of Educational Research, vol. 8, no. 4A, pp. 45-50, 2020.

[29] R. Komala, et al., "Group investigation model in environmental learning: An effect for students' higher order thinking skills," Universal Journal of Educational Research, vol. 8, no. 4A, pp. 9-14, 2020.

[30] F. D. Yusop and M. Sumari, "The Use of Social Media Technologies among Malaysian Youth," Procedia - Social and Behavioral Sciences, vol. 103, pp. 1204-1209, 2013.

[31] J. M. Urbani, et al., "Developing and modeling 21st-century skills with preservice teachers," Teacher Education Quarterly, vol. 44, no. 4, pp. 27-51, 2017.

[32] X. Xuan, et al., "The Potential Contribution of Geography Curriculum to Scientific Literacy," Journal of Geography, vol. 118, no. 5, pp. 185-196, 2019.

[33] A. C. Saputri, et al., "Improving students' critical thinking skills in cell-metabolism learning using stimulating higher order thinking skills model," International Journal of Instruction, vol. 12, no. 1, pp. 327-342, 2019.

[34] D. J. Camacho and J. M. Legare, "Opportunities to create active learning techniques in the classroom," Journal of Instructional Research, vol. 4, pp. 38-45, 2015.

[35] L. F. Santos, "The role of critical thinking in science education," Journal of Education and Practice, vol. 8, no. 20, pp. $158-173,2017$.

[36] S. S. Anagun, "Teachers' perceptions about the relationship between 21 st century skills and managing constructivist learning environments," International Journal of Instruction, vol. 11, no. 4, pp. 825-840, 2018.

[37] L. W. Lee, A. R. Mohamed, and A. A. Altamimi, "Design, Development, and Evaluation of an Automated eLearning Tutorial System to Instruct Pre-Service Special Educators in the Malay Braille Code," Asia-Pacific Education Researcher, vol. 24, no. 3, pp. 481-494, 2015.

[38] T. L. Chou, et al., "Research Trends and Features of Critical Thinking Studies in E-Learning Environments: A Review," Journal of Educational Computing Research, vol. 57, no. 4, 2019.

[39] S. N. Kew, et al., "Examining the motivation level of students in e-learning in higher education institution in Thailand: A case study," Education and Information Technologies, vol. 23, no. 6, pp. 2947-2967, 2018.

[40] M. Miarsyah, D. V. Sigit, I. Z. Ichsan, R. Fadrikal, and M. Suprapto, "Lekersmulia: Improving indonesian students' environmental responsibility using multimedia in environmental learning," International Journal of Scientific and Technology Research, vol. 8, no. 12, pp. 1639-1643, 2019.

[41] H. Rahmayanti, et al., "Development of sorting waste game android based for early childhood in environmental education," Journal of Physics: Conference Series, vol. 1434, no. 1, pp. 012029, 2020. 